\title{
APLIKASI GLIOCOMPOST UNTUK MENINGKATKAN PERTUMBUHAN BIBIT PADI PANDANWANGI (Oryza sativa L.var.Aromatic)
}

\author{
Oleh: \\ Hani Gani Asih *) \\ Melissa Syamsiah **) \\ Email : $\underline{\text { Haniganiasih99@gmail.com, melissasyamsiah@gmail.com }}$
}

\begin{abstract}
Abstrak
Padi Pandanwangi merupakan varietas lokal yang berasal dari Cianjur yang memerlukan usaha dalam produksi beras pandanwangi yaitu dengan cara perbaikan teknologi dalam budidaya untuk dapat memenuhi permintaan pasar akan beras Pandanwangi. Teknologi yang dapat diterapkan dalam budidaya padi Pandanwangi diantaranya dengan menggunakan Gliocompost pada media tanamnya. Penelitian ini bertujuan untuk: mengetahui pengaruh pemberian Gliocompost terhadap pertumbuhan bibit padi Pandanwangi. Penelitian dilaksanakan di Screenhouse Fakultas Sains Terapan Universitas Suryakancana Cianjur. Waktu penelitian dilaksanakan pada bulan Februari hingga Mei 2018. Penelitian menggunakan rancangan acak lengkap (RAL) satu faktor yang terdiri dari 4 perlakuan dan 6 ulangan. Perlakuannya yaitu P1: Tanpa Gliocompost (kontrol), P2: Pemberian Gliocompost sebanyak 2gr/kg tanah, P3: Pemberian Gliocompost sebanyak 4gr/kg tanah dan P4: Pemberian Gliocompost sebanyak $6 \mathrm{gr} / \mathrm{kg}$ tanah. Hasil penelitian menunjukkan bahwa perlakuan yang paling baik yaitu perlakuan P2 (2gr/ kg tanah), P3 (4gr/ kg tanah) dan P4 (6gr/ kg tanah). Aplikasi Gliocompost dengan dosis $2 \mathrm{gr} / \mathrm{kg}$ tanah (perlakuan P2) memberikan pengaruh paling baik terhadap benih berkecambah, banyak daun, panjang akar dan berat basah bibit padi Pandanwangi. Sedangkan untuk tinggi tanaman perlakuan yang paling baik yaitu perlakuan P4 (6gr/ kg tanah). Dengan kata lain aplikasi Gliocompost pada media tanam padi Pandanwangi ini memberikan pengaruh yang paling baik dibandingkan dengan tanpa pemberian Gliocompost.
\end{abstract}

Kata Kunci: Bibit, Gliocompost, Media tanam, Padi Pandanwangi.

\begin{abstract}
Pandanwangi rice is a local variety that comes from Cianjur, its existence has been famous to foreign countries because of its superiority. It was necessary to increase the production of pandanwangi rice by improving technology in cultivation for market demand on Pandanwangi rice. One of technology that can be applied in Pandanwangi rice cultivation was by using Gliocompost application on planting medium. This research aimed to: know the effect of Gliocompost on the number of seeds germinated, seedlings height, leaves numbers, root length and wet weight of Pandanwangi rice seedlings. The research was conducted at Screenhouse of Applied Science Faculty Universitas Suryakancana Cianjur,in February to May 2018. The design used was a complete randomized design (CRD) of one factor consisting of 4 treatments and 6 replications. The treatment were P1: Without Gliocompost (control), P2: Gliocompost 2gr/ kg of soil, P3: Gliocompost of $4 \mathrm{gr} / \mathrm{kg}$ of soil and P4: Gliocompost of $6 \mathrm{gr} / \mathrm{kg}$ of soil. The results showed that the best treatment were P2 (2gr/ $\mathrm{kg}$ soil), P3 (4gr/ $\mathrm{kg}$ soil) and P4 (6gr/ $\mathrm{kg}$ soil) treatment. The application of Gliocompost (P2 treatment) gave the best effect to the germinating seeds, leaves numbers, root length and wet weight of Pandanwangi rice seedlings. While for the best treatment plant height was P4 treatment $(6 g \mathrm{r} / \mathrm{kg})$.
\end{abstract}


Gliocompost application on Pandanwangi planting media gave the best effect compared with without giving Gliocompost.

Keywords: Gliocompost, Pandanwangi rice, Planting media, Seedlings.

*) Alumni Fakultas Sains Terapan UNSUR

**) Dosen Fakultas Sains Terapan UNSUR 


\section{PENDAHULUAN}

Padi Pandanwangi (Oryza sativa $\mathrm{L}$. var.Aromatica) merupakan varietas lokal yang berasal dari Cianjur, eksistensinya sudah terkenal hingga mancanegara karena keunggulannya tersebut. Beras Pandanwangi digemari karena memiliki keunggulan seperti: rasanya enak, pulen, dan ber-aroma wangi seperti pandan. Karena keunggulan yang dimilikinya tersebut membuat harga berasnya lebih mahal dibandingkan dengan harga beras varietas lain.

Namun banyak kendala dalam budidaya padi Pandanwangi ini. Hanya daerah tertentu yang dapat menghasilkan beras Pandanwangi yang memiliki kualitas yang baik dikarenakan padi Pandanwangi hanya dapat tumbuh dengan baik di tanah andosol/regina. Tanah andosol/regina ini hanya terdapat di Kecamatan, Warungkondang, Cugenang, Cibeber, Cianjur, dan kecamatan Cilaku. Itulah mengapa Pandanwangi dengan kualitas terbaik hanya bisa diperoleh di 5 kecamatan itu. Jika ditanam di luar wilayah itu, rasa Pandanwangi akan berbeda dan aromanya tidak muncul, apalagi jika ditanam di luar Cianjur (Tatty et al., 2015).

Beberapa faktor berpengaruh terhadap menurunnya produksi beras Pandanwangi. Diantaranya, waktu masa tanam budidaya padi Pandanwangi yang lebih lama menyebabkan hanya sedikit petani yang tertarik untuk budidaya padi Pandanwangi. Adanya perubahan musim dan cuaca juga menjadi penyebab menurunnya produksi beras. Selain itu alih fungsi lahan menyebabkan areal penanaman padi menjadi lebih sedikit. Keadaan ini juga diperburuk dengan adanya krisis ekonomi yang berdampak pada menurunnya daya beli petani terhadap kebutuhan produksi terutama pupuk dan pestisida (Purnamaningsih, 2006).

Perlu adanya usaha yang dapat meningkatkan produktivias beras Pandanwangi dengan tetap mempertahankan kualitasnya. Salah satunya yaitu dengan perbaikan teknologi dalam budidaya padi Pandanwangi dengan menggunakan Gliocompost untuk menggantikan pupuk kimia sintetik. Gliocompost ini adalah bahan organik dalam bentuk compost. Didalamnya terdapat berbagai mikroba yang berperan sebagai pemacu pertumbuhan tanaman seperti: Azotobacter sp., Azospirillum sp., Bacillus sp. dan Gliocladium sp. Kelebihan dari bahan organik ini yaitu dapat berfungsi sebagai pupuk yang berguna untuk menunjang pertumbuhan tanaman dan menekan kehilangan hasil yang diakibatkan oleh serangan Organisme Pengganggu Tumbuhan (OPT) serta dapat menjaga kualitas hasil pertanian (BPTPH, 2010).

Biakan cendawan Gliocladium sp. yang diaplikasikan ke lahan tanam berlaku sebagai biodekomposer yang dapat mendekomposisi limbah organik menjadi kompos yang bermutu. Biakan cendawan Gliocladium sp. juga dapat berperan sebagai biofungisida dalam mengendalikan organisme patogen penyebab penyakit tanaman. Aplikasi Gliocladium sp. ke lahan tanam sangat diperlukan untuk menambah populasinya agar dapat mengendalikan cendawan pathogen. Hal ini disebabkan dengan semakin banyak populasi Gliocladium sp. di dalam tanah daya antagonisnya akan semakin besar. Selain itu, kemampuan antibiotik yang dihasilkan akan semakin baik untuk membunuh patogen (Iskandar dan Pinem 2009).

Berdasarkan latar belakang di atas dilakukan penelitian yang bertujuan untuk mengetahui pengaruh pemberian Gliocompost terhadap pertumbuhan bibit padi Pandanwangi.

\section{METODE PENELITIAN}

Penelitian dilaksanakan di Screenbouse Fakultas Sains Terapan (FASTER) Universitas Suryakancana Cianjur. Waktu penelitian dilaksanakan 
pada bulan Februari hingga bulan Mei 2018.

Alat yang digunakan dalam penelitian yaitu: ember, sekop, gembor, penggaris, timbangan analitik, paranet, lakban, label, tisu. Adapun bahan yang digunakan dalam penelitian ini yaitu: Gliocompost yang didapatkan dari Balai Penelitian Tanaman Hias (BALITHI) yang bertempat Jl. Raya Ciherang, Segunung Pacet Cianjur 51260 - Jawa Barat; benih padi Pandanwangi yang berasal dari Koperasi Mitra Tani Parahyangan Warungkondang; air; garam; tanah sebagai media tanam yang diambil dari pesawahan padi Pandanwangi yang bertempat di Warungkondang.

Rancangan yang digunakan dalam penelitian ini adalah rancangan acak lengkap (RAL) satu faktor yang terdiri dari 4 perlakuan dan 6 ulangan. Adapun perlakuannya sebagai berikut :

A. Tanpa pemberian Gliocompost (kontrol)

B. Pemberian Gliocompost sebanyak $2 \mathrm{gr} / \mathrm{kg} \tan a \mathrm{~h}$

C. Pemberian Gliocompost sebanyak $4 \mathrm{gr} / \mathrm{kg} \tan a \mathrm{~h}$

D. Pemberian Gliocompost sebanyak $6 \mathrm{gr} / \mathrm{kg} \tan a \mathrm{~h}$

Setiap perlakuan terdiri dari 6 ulangan dan setiap unit perlakuan terdiri dari 20 tanaman, sehingga total tanaman dalam penelitian ini sebanyak 480 tanaman. ini berupa:

Adapun hipotesis dalam penelitian

H0 : Pemberian Gliocompost tidak berpengaruh terhadap pertumbuhan bibit padi Pandanwangi.

H1 : Pemberian Gliocompost berpengaruh terhadap pertumbuhan bibit padi Pandanwangi.

Pelaksanaan penelitian terdiri dari beberapa kegiatan sebagai berikut :
Persiapan Alat dan Baban: Mempersiapkan peralatan dan bahan yang digunakan dalam penelitian.

Penyiapan Laban: Menyiapkan lahan penunjang penelitian berupa Screenhouse yang bertempat di Fakultas Sains Terapan, Universitas Suryakancana Cianjur. Sebelum melakukan penelitian, maka lahan yang akan digunakan untuk penelitian dibersihkan dahulu dari hal-hal yang akan mengganggu berjalannya penelitian.

Persiapan Benib: Benih yang digunakan didapatkan dari koperasi Mitra Tani Parahyangan yang bertempat di kecamatan Warungkondang. Benih tersebut merupakan benih yang biasa digunakan petani didaerah tersebut yang sudah hasil seleksi. Benih yang digunakan sebanyak 480 benih. Sebelum melakukan penyemaian benih disortasi terlebih dahulu untuk memisahkan benih yang hampa dan benih yang bernas. Benih direndam dalam air garam (pemberian garam sebanyak 4\% dari volume air), benih yang mengapung dibuang (hampa). Benih yang tenggelam (bernas) dicuci hingga tidak ada kandungan garam yang menempel di benih. Setelah benih melewati proses sortasi selanjutnya benih direndam selama 30 menit didalam air, selanjutnya benih diperam selama 24 jam (Tarigan, et al., 2013).

Persiapan Media: Media tanam yang digunakan adalah tanah (diambil dari sawah padi Pandanwangi yang bertempat didaerah Warungkondang). Sebelum membuat media tanam, Gliocompost yang akan digunakan ditimbang terlebih dahulu sesuai dengan perlakuan yang akan diberikan, yaitu 2 gr, 4 gr dan 6 gr. Karena dalam 1 ember berisi $2 \mathrm{~kg}$ tanah, maka setiap perlakuan dikalikan dengan 2 . Kemudian media tanam (tanah) ditimbang dan dimasukkan ke dalam ember sebanyak 24 unit, lalu dicampurkan dengan Gliocompost hingga tercampur rata. Setiap perlakuan diulang sebanyak 6 kali (6 ember). Dengan demikian media sudah 
siap ditanami dengan tanaman padi Pandanwangi.

Pemberian Label: Setiap ember diberi label sesuai dengan unit perlakuan, kemudian diberikan stik kayu yang telah diberi angka untuk mempermudah pada saat menginput data penelitian. Jumlah stik kayu yang digunakan yaitu 20 batang/ember karena pada penelitian ini menggunakan 20 tanaman dalam 1 embernya.

Penempatan Unit Perlakuan (ember): Ember yang telah diberi label kemudian diletakan sesuai dengan tata letak unit penelitian yang telah diacak.

Penanaman Setelah benih disortasi dan diperam kemudian benih ditanam pada media tanam berupa tanah yang telah diberi perlakuan Gliocompost. Penanaman dilakukan secara hati-hati. Setiap lubang berisi 1 tanaman, dan setiap ember berisi 20 tanaman.

Pemeliharaan: Pemeliharaan yang dilakukan yaitu meliputi pengendalian organisme penggangu tanaman (OPT), sanitasi dan juga pemberian Gliocompost. Karena umur tanaman padi pandanwangi 6 bulan, maka biasanya petani padi Pandanwangi melakukan pemupukan sebanyak tiga kali. Pertama saat waktu tanam, kedua waktu umur tanaman menginjak 3 minggu, ketiga yaitu pada waktu fase primordia (pembentukan malai) yakni umur tanaman 60 hari. Oleh karena penelitian ini hanya dilakukan hingga fase vegetatif (35 hari), maka pemberian/aplikasi Gliocompost dilakukan hanya 2 kali yaitu pada saat tanam dan 3 minggu setelah tanam.

Pengamatan: Pengamatan dilakukan sejak 7 hst hingga 35 hst, waktu pengamatan setiap parameter berbeda-beda. Data yang diperoleh dicatat sesuai dengan label yang diberikan untuk menghasilkan data yang sesuai.

\section{Parameter Penelitian}

\section{Benih Berkecambah Padi Pandanwangi}

Untuk mendapatkan data jumlah benih berkecambah yaitu dengan melihat radikula yang sudah muncul. Benih yang berkecambah dihitung pada saat 7 hst. Kemudian data yang dihasilkan diolah dengan menggunakan rumus persentase benih berkecambah, yaitu sebagai berikut:

Keterangan:

$$
\mathrm{G}=\mathrm{A} / \mathrm{B} \times 100 \%
$$

$\mathrm{G}=$ Persentase Jumlah Benih

Berkecambah A = Jumlah benih yang

berkecambah

$\mathrm{B}=$ Jumlah benih yang dikecambahkan

\section{Tinggi Bibit Padi Pandanwangi (cm)}

Pengukuran tinggi bibit padi Pandanwangi dilakukan dengan cara diukur dengan menggunakan penggaris dengan satuan (cm). Bibit padi Pandanwangi diukur dari pemukaan tanah hingga pucuk tanaman yang paling atas. Tinggi tanaman diukur sejak 7 hst hingga 35 hst, dengan interval 7 hari. Sehingga dihasilkan 5 data pengamatan jumlah daun bibit padi Pandanwangi.

Jumlah Daun Bibit Padi Pandanwangi (helai) Jumlah daun bibit padi Pandanwangi dihitung dengan cara dilihat daun bibit padi Pandanwangi yang telah membuka pada saat pengamatan. Dihitung sejak 7 hst hingga 35 hst, dengan interval 7 hari. Sehingga dihasilkan 5 data pengamatan jumlah daun bibit padi Pandanwangi.

Panjang Akar Bibit Padi Pandanwangi (cm) Dilakukan pada saat padi Pandanwangi pada 35 hst. Sebelum melakukan pengukuran panjang akar, terlebih dahulu bibit padi Pandanwangi dicabut. Pencabutan bibit padi Pandanwangi dilakikan dengan perlahan dari media tanamnya. Pada penelitian ini media yang digunakan berupa tanah, dimana struktur tanah yang padat membuat perakaran sulit 
dicabut. Untuk itu agar akar tidak putus saat dicabut maka terlebih dahulu tanah diremahkan sehingga terdapat rongga untuk memudahkan pencabutan akar, barulah tanaman dicabut dari perakaran dengan sangat hati-hati. Setelah itu, akar bibit padi Pandanwangi diukur dengan menggunakan penggaris dalam satuan (cm). Pengukuran dilakukan dari pangkal akar sampai ujung akar dengan membentangkan akar.

\section{Bobot Segar Bibit Padi Pandanwangi (gram)}

Bobot segar bibit padi Pandanwangi ditimbang dengan menggunakan timbangan analitik (dua digit dibelakang koma) dengan satuan (gram), yang dilakukan pada saat 35 hst atau setelah pengamatan panjang akar. Bibit padi Pandanwangi yang telah dicabut dari media kemudian dibersihkan dari tanah yang menempel dengan cara mencucinya dengan air secara perlahan agar tidak ada bagian yang rusak/terputus, kemudian bibit padi Pandanwangi tersebut dikeringkan dengan menggunakan tisu, karena jika tidak dilakukan pengeringan maka air dari proses pencucian akan menempel ditanaman dan mempengaruhi berat bibit padi Pandanwangi tersebut. Penimbangan dengan cara menimbang seluruh bagian tanaman.

\section{HASIL DAN PEMBAHASAN}

\section{Benih Berkecambah}

Parameter pertama yang diamati pada peneitian ini adalah pengaruh pemberian Gliocompost pada media tanam terhadap jumlah benih padi Pandanwangi (Oryza sativa L. var.Aromatic) berkecambah. Hasil dari uji ANOVA menunjukkan pemberian perlakuan Gliocompost berpengaruh terhadap jumlah benih yang berkecambah pada taraf $\alpha=5 \%$.

Tabel 1. Hasil ANOVA Pengujian Perlakuan Gliocompost pada Media Tanam terhadap Benih Berkecambah Padi Pandanwangi.

\begin{tabular}{cc}
\hline Perlakuan & Benih Berkecambah (\%) \\
\hline P12) & $42 \mathrm{~b}^{1)}$ \\
P2 & $50 \mathrm{a}$ \\
P3 & $47 \mathrm{ab}$ \\
P4 & $48 \mathrm{a}$
\end{tabular}

1) Angka pada lajur yang sama diikuti oleh huruf yang sama tidak berbeda nyata menurut uji Tukey pada taraf $5 \%$ 2) $\mathrm{P} 1=$ Kontrol, $\mathrm{P} 2=$ Gliocompost $2 \mathrm{gr} / \mathrm{kg}$ tanah, $\mathrm{P} 3=$ Gliocompost $4 \mathrm{gr} / \mathrm{kg}$ tanah, $\mathrm{P} 4$ $=$ Gliocompost $6 \mathrm{gr} / \mathrm{kg}$ tanah

Dalam pengujian benih, salah satu persyaratan tumbuh yang paling penting adalah substrat/media tumbuh benih. Salah satu faktor yang dapat mempengaruhi perkecambahan benih adalah media perkecambahan. Pada beberapa benih tertentu, substrat perkecambahan dapat menyebabkan benih menjadi dorman (Enforced Domancy). Media yang digunakan untuk pengujian perkecambahan adalah produk yang menyediakan cukup ruang pori untuk udara dan air, untuk sistem pertumbuhan akar dan untuk kontak dengan larutan (air) yang diperlukan untuk pertumbuhan tanaman. Beberapa hal yang menjadi spesifikasi untuk seluruh media perkecambahan dan harus dipenuhi adalah komposisi media, karakter retensi air, $\mathrm{pH}$, konduktivitas, kebersihan dan bebas dari zat toksik, dan penggunaan ulang substrat (ISTA, 2014).

Kelebihan dalam penggunaan arang sekam dalam bahan baku pembuatan Gliocompost yaitu dapat memperbaiki siklus air dan udara di dalam tanah, dapat membangun kesuburan tanah, membantu menstabilkan kemasaman tanah sehingga pada akhirnya dapat merangsang pertumbuhan tanaman. Wasito dan Marwoto (2003) menyebutkan bahwa penggunaan Gliocompost di persemaian yang tepat dosis dengan komposisi campuran yang tepat, selain mampu menanggulangi kerugian akibat serangan 
penyakit tular tanah juga mampu meningkatkan kesuburan tanaman.

Adapun Azospirillum yang berperan dalam pengaturan keseimbangan unsur organik tanah dan peningkatan pertumbuhan tanaman (Rao, 1982). Kemampuan bakteri tersebut dalam meningkatkan pertumbuhan tanaman karena produksi fitohormon (auksin, giberelin dan sitokinin) (Fallik et al., 1989). Dimana hormon Giberelin adalah hormon tumbuhan yang berperan dalam proses perkembangan dan perkecambahan. Giberelin akan merangsang pembentukan enzim amilase yang berfungsi untuk memecah senyawa amilum yang terdapat di endosperm (cadangan makanan) menjadi senyawa glukosa. Glukosa tersebut menjadi sumber energi bagi pertumbuhan tanaman (Wattimena, 1987)

\section{Tinggi Bibit}

Parameter kedua yang diamati pada penelitian ini adalah pengaruh pemberian Gliocompost terhadap tinggi tanaman bibit padi Pandanwangi. Hasil uji ANOVA pemberian perlakuan Gliocompost pada media tanam terhadap tinggi tanaman bibit padi Pandanwangi secaraumum menunjukkan pemberian perlakuan Gliocompost berpengaruh terhadap tinggi tanaman bibit padi Pandanwangi pada $\operatorname{taraf} \alpha=5 \%$.

Tabel 2. Hasil ANOVA Pengujian Perlakuan Gliocompost pada Media Tanam terhadap Tinggi Bibit Bibit Padi Pandanwangi (cm).

\begin{tabular}{|c|c|c|c|c|c|}
\hline Perlakuan & $\begin{array}{c}7 \\
\text { hst }\end{array}$ & $\begin{array}{l}14 \\
\text { hst }\end{array}$ & $\begin{array}{c}21 \\
\text { hst }\end{array}$ & $\begin{array}{c}28 \\
\text { hst }\end{array}$ & $\begin{array}{c}35 \\
\text { hst }\end{array}$ \\
\hline $\mathrm{P}^{2)}$ & 6,15 & 18,08 & 25,28 & 32,94 & 40,47 \\
\hline $\mathbf{P} 2$ & $\begin{array}{c}\mathrm{b} 1) \\
6,70 \\
\mathrm{ab}\end{array}$ & $\begin{array}{c}\mathrm{b} \\
18,87 \\
\mathrm{~b}\end{array}$ & $\begin{array}{c}\mathrm{b} \\
28,34 \\
\mathrm{~b}\end{array}$ & $\begin{array}{c}c \\
38,84 \\
b\end{array}$ & $\begin{array}{c}c \\
48,76 \\
b\end{array}$ \\
\hline P3 & 8,81 & 21,88 & 33,45 & 41,64 & 50,74 \\
\hline \multirow[t]{2}{*}{ P4 } & $\begin{array}{c}a \\
8,01\end{array}$ & $\begin{array}{c}\mathrm{ab} \\
24,10\end{array}$ & $\begin{array}{c}\mathrm{a} \\
35,02\end{array}$ & $\begin{array}{c}\mathrm{ab} \\
44,33\end{array}$ & $\begin{array}{c}\mathrm{ab} \\
53,34\end{array}$ \\
\hline & $\mathrm{ab}$ & $\mathrm{a}$ & $\mathrm{a}$ & $\mathrm{a}$ & $\mathrm{a}$ \\
\hline
\end{tabular}

1)Angka pada lajur yang sama diikuti oleh huruf yang sama tidak berbeda nyata menurut uji Tukey pada taraf $5 \%$ 2) P1 = Kontrol, P2 = Gliocompost 2 gr $/ \mathrm{kg}$ tanah, P3 = Gliocompost $4 \mathrm{gr} / \mathrm{kg}$ tanah, P4 $=$ Gliocompost $6 \mathrm{gr} / \mathrm{kg}$ tanah.

Tinggi tanaman merupakan ukuran pertumbuhan tanaman yang paling mudah diamati dalam melihat pengaruh suatu aplikasi perlakuan (Sitompul dan Guritno, 1995). Tinggi tanaman padi diukur dari permukaan tanah sampai ujung tanaman yang paling tinggi. Pengukuran tinggi tanaman padi Pandanwangi pada penelitian ini diamati dengan interval 7 hari yang dilakukan dari 7 hst sampai dengan 35 hst.

Adanya penambahan Gliocompost pada media tanam. Menurut Bonde et al., (1995) Gliocompost mampu berperan sebagai pengurai bahan organik bagi pertanaman. Sehingga tanaman yang media tanamnya menggunakan aplikasi Gliocompost menghasilkan tinggi tanaman yang lebih baik dibandingkan dengan perlakuan yang tidak menggunakan aplikasi Gliocompost.
Sekam padi yang digunakan sebagai media perlakuan banyak menyediakan komponen anorganik dan organik (selulosa, lignin, kitin, karbohidrat, nitrogen dan lipid). Karbohidrat dan selulosa yang ada dimanfaatkan oleh Gliocladium sp. sebagai sumber energi dan sumber karbon untuk membantu dalam proses dekomposisi tersebut. Pada saat jumlah nitrogen tercukupi, pembentukan auksin baik dan akhirnya pertumbuhan tinggi tanaman akan lebih baik. Pertumbuhan tanaman terutama pada tinggi tanaman sangat dipengaruhi oleh fitohormon, yaitu auksin. Sebagaimana diketahui dalam komposisi Gliocompost terdapat Azospirillum yang memiliki kemampuan dalam memproduksi fitohormon (auksin, giberelin dan sitokinin) (Fallik et al., 1989). Auksin yang dihasilkan oleh ujung tanaman 
berpengaruh langsung pada pucuk tanaman yang terbentuk karena adanya nitrogen, ketersediaan unsur hara nitrogen juga berpengaruh pada perbedaan tinggi tanaman. Selain nitrogen, unsur hara kalium juga berperan pada pertumbuhan, karena berpengaruh langsung pada pembentukan sel pada tanaman dan juga membantu perkembangan akar tanaman.

Selain itu kandungan unsur hara magnesium, fosfor, kalium, mangan, dan nitrogen yang berasal dari perombakan bahan organik berpengaruh terhadap pertumbuhan tanaman. Secara fisik, keberadaan bahan organik dalam tanah dapat membantu proses agregasi sehingga akan terbentuk agregat yang mantap (Taiz dan Zeiger, 2007). Terkait dengan fenomena tersebut miselium Gliocladium sp. akan mempertahankan bagian tanah sehingga akan membentuk struktur yang remah, sehingga akar tanaman akan lebih mudah berkembang dan penyerapan terhadap air dan kandungan unsur hara baik makro dan mikro lebih terpenuhi untuk pertumbuhan diantaranya untuk tinggi tanaman.

Pada awal pertumbuhan, perlakuan pemberian Gliocompost belum berpengaruh nyata terhadap tinggi bibit padi Pandanwangi. Hal ini disebabkan pada awal pertumbuhan tanaman belum mendapat kandungan unsur hara yang lebih banyak dan masih adaptasi dengan lingkungan. Selain itu juga disebabkan karena jumlah daun yang masih sedikit sehingga proses fotosintat masih sedikit dan menyebabkan laju pertumbuhan masih lambat. Namun jika dilihat secara numerik perlakuan yang menggunakan aplikasi Gliocompost, pertumbuhan tingginya lebih baik dibandingkan dengan perlakuan yang tanpa menggunakan aplikasi Gliocompost (kontrol).

\section{Banyak Daun}

Parameter ketiga yang diamati yaitu banyak daun, diamati pada 7 hst, 14 hst, 21 hst, 28 hst dan 35 hst. Hasil uji ANOVA pemberian perlakuan Gliocompost pada media tanam terhadap jumlah daun bibit padi Pandanwangi (Oryza sativa L. var. Aromatic) secara umum menunjukkan pemberian perlakuan Gliocompost berpengaruh terhadap banyak daun bibit padi Pandanwangi pada taraf $\alpha=5 \%$.

Tabel 3. Hasil ANOVA Pengujian Perlakuan Gliocompost pada Media Tanam terhadap Banyak Daun Bibit Padi Pandanwangi (helai).

\begin{tabular}{|c|c|c|c|c|c|}
\hline Perlakuan & $\begin{array}{c}7 \\
\text { hst }\end{array}$ & $\begin{array}{c}14 \\
\text { hst }\end{array}$ & $\begin{array}{l}21 \\
\text { hst }\end{array}$ & $\begin{array}{l}28 \\
\text { hst }\end{array}$ & $\begin{array}{l}35 \\
\text { hst }\end{array}$ \\
\hline $\mathbf{P 1}^{23}$ & $\begin{array}{c}1,73 \\
b^{13}\end{array}$ & $2,20 \mathrm{c}$ & $\begin{array}{c}3,00 \\
b\end{array}$ & $\begin{array}{c}3,00 \\
b\end{array}$ & $\begin{array}{c}4,53 \\
b\end{array}$ \\
\hline $\mathbf{P 2}$ & $\underset{\mathbf{a}}{2,03}$ & 3,10 a & 3,83 a & 4,70 a & 5,67 a \\
\hline P3 & $\begin{array}{c}2,03 \\
a\end{array}$ & $\begin{array}{c}2,90 \\
\mathbf{a b}\end{array}$ & $3,60 \mathrm{a}$ & 4,47 a & 5,40 a \\
\hline P4 & $\begin{array}{c}2,06 \\
\text { a }\end{array}$ & $\begin{array}{c}2,67 \\
b\end{array}$ & 3,43 a & $\begin{array}{c}4,30 \\
\mathrm{ab}\end{array}$ & 5,23 a \\
\hline
\end{tabular}

1) Angka pada lajur yang sama diikuti oleh huruf yang sama tidak berbeda nyata menurut uji Tukey pada taraf $5 \%$ 2) $\mathrm{P} 1=$ Kontrol, $\mathrm{P} 2=$ Gliocompost $2 \mathrm{gr} / \mathrm{kg}$ tanah, $\mathrm{P} 3=$ Gliocompost $4 \mathrm{gr} / \mathrm{kg}$ tanah, $\mathrm{P} 4=$ Gliocompost $6 \mathrm{gr} / \mathrm{kg}$ tanah.

Daun merupakan organ penting bagi tumbuhan. Daun memiliki peranan penting dalam melakukan proses fotosintesis. Parameter jumlah daun juga merupakan parameter pertumbuhan yang mudah diamati. Menurut Santosa (1993) pola perkembangan tumbuhan ditentukan oleh kerja sama antara faktor genetik dan faktor dalam lainnya dengan lingkungan.
Salah satu faktor lingkungan tersebut adalah cahaya, kelembaban, curah hujan dan ketinggian tempat, serta faktor dalam diantaranya adalah zat pengatur tumbuh dan fitohormon.

Gliocompost diketahui mengandung berbagai mikroorganisme yang dapat memberikan berbagai keuntungan bagi tanaman. Gliocladium sp. diketahui 
merupakan mikroorganisme yang berperan sebagai bahan organik bagi pertanaman (Baker dan Cook. 1983). Aplikasi Azospirillum sp. dan Azotobacter sp., baik tunggal maupun campuran meningkatkan $\mathrm{N}$ total tanah, serapan $\mathrm{N}$ tanaman, Jumlah anakan dan hasil padi. Hal ini mengindikasikan bahwa kedua bakteri tersebut dapat dikembangkan sebagai pupuk hayati pada tanaman padi sawah. Menurut Hutasoit (2011), nitrogen merupakan unsur yang sangat penting dalam pertumbuhan tanaman. Nitrogen merupakan unsur terpenting dalam pembentukan atau pembelahan sel yang merupakan salah satu unsur pembentuk klorofil dalam tanaman, dan juga merupakan sumber protein bagi tanaman. Diperkuat dengan pernyataan Budiyanto (2009), menyatakan bahwa nitrogen adalah unsur hara utama dalam klorofil, protoplasma, dan protein. Berdasarkan pernyataan di atas dapat dipastikan bahwa peningkatan unsur nitrogen dapat menambah pertumbuhan jumlah daun, karena pada dasarnya klorofil tertinggi yaitu pada bagian daun. Kelebihan dalam penggunaan arang sekam dalam bahan baku pembuatan Gliocompost dapat memperbaiki siklus air dan udara di dalam tanah, dapat membangun kesuburan tanah, membantu menstabilkan kemasaman tanah sehingga pada akhirnya dapat merangsang pertumbuhan tanaman terutama pada pertumbuhan jumlah daun. Oleh karena itu, Gliocompost yang diberikan ke media tanam bibit padi Pandanwangi ini mampu menyediakan lebih banyak nutrisi, sehingga pertumbuhannya lebih baik.

\section{Panjang Akar}

Parameter keempat yang diamati pada peneitian ini adalah pengaruh pemberian Gliocompost pada media tanam terhadap panjang akar bibit padi Pandanwangi (Oryza sativa L. var.Aromatic). Hasil uji ANOVA pemberian perlakuan Gliocompost pada media tanam (Oryza sativa L. var. Aromatic) menunjukkan pemberian perlakuan Gliocompost berpengaruh terhadap tinggi tanaman bibit padi pandanwangi pada $\operatorname{taraf} \alpha=5 \%$.

Tabel 4. Hasil ANOVA Pengujian Perlakuan Gliocompost pada Media Tanam terhadap Panjang Akar Padi Pandanwangi (cm).

\begin{tabular}{cc} 
Perlakuan & Panjang Akar (cm) \\
\hline P12) & $4,53 \mathrm{~b}^{1)}$ \\
P2 & $5,67 \mathrm{a}$ \\
P3 & $5,40 \mathrm{a}$ \\
P4 & $5,23 \mathrm{a}$ \\
\hline
\end{tabular}

\footnotetext{
1) Angka pada lajur yang sama diikuti oleh huruf yang sama tidak berbeda nyata menurut uji Tukey pada taraf $5 \%{ }^{2)} \mathrm{P} 1=$ Kontrol, $\mathrm{P} 2=$ Gliocompost $2 \mathrm{gr} / \mathrm{kg}$ tanah, $\mathrm{P} 3=$ Gliocompost $4 \mathrm{gr} / \mathrm{kg}$ tanah, $\mathrm{P} 4=$ Gliocompost $6 \mathrm{gr} / \mathrm{kg}$ tanah.
}

Hasil penelitian dalam tabel 5 . menunjukkan bahwa panjang akar paling baik yaitu perlakuan P2 (Gliocompost $2 \mathrm{gr} / \mathrm{kg}$ tanah) dengan nilai rata-rata 5,67 $\mathrm{cm}$. Nilai ini tidak berbeda nyata dengan perlakuan P3 (Gliocompost 4gr/kg tanah) dan P4 (Gliocompost 6gr/kg tanah) dengan rata-rata nilai panjang akar bibit $5,40 \mathrm{~cm}$ dan $5,23 \mathrm{~cm}$. Hal tersebut terjadi karena ketiga perlakuan tersebut menggunakan aplikasi Gliocompost pada media tanamnya. Seperti yang diketahui, komposisi dalam Gliocompost terdiri atas Azotobacter sp.,
Azospirillum sp., Basillus sp., Gliocladium sp., pupuk kandang, dedak dan arang sekam. Menurut Putri (2008), pada media yang digunakan penambahan bahan organik berupa arang sekam akan memperbaiki struktur media tumbuh menjadi lebih remah dibandingkan dengan tanah saja, hal ini menyebabkan akar dapat bergerak ke segala arah. Sehingga akar dapat tumbuh dengan optimal. Sistem perakaran tanaman sangat dipengaruhi oleh faktor genetik dan media tanah sebagai media tumbuh tanaman. 
Sebagian besar unsur hara yang dibutuhkan tanaman diserap dari larutan tanah melalui akar, kecuali karbon dan oksigen yang diserap dari udara oleh daun. Panjangnya akar berpengaruh terhadap ketersediaan larutan nutrisi yang diserap tanaman dan penyerapan air dari tanah. Artinya semakin banyak dan panjang akar tanaman maka akan semakin besar cakupan akar untuk menyerap air dan unsur hara dalam media tanam tanaman sehingga kebutuhan hara untuk pertumbuhan dan produksi tanaman semakin terjamin (Lakitan, 2007). Hasil penelitian menunjukkan perlakuan yang tanpa menggunakan aplikasi Gliocompost yaitu perlakuan P1 (kontrol) panjang akarnya paling pendek pertumbuhannya, hal ini dikarenakan tidak ada bahan organik yang dapat memperbaiki struktur media tanam. Russel (1977) menyebutkan tanah yang memiliki tingkat kepadatan tinggi total panjang akarnya rendah, jika kepadatan tanah meningkat maka ruang pori makro menurun dan penetrasi akar dihambat. Tiap tanaman mengeluarkan eksudat akar dengan komposisi yang berbeda sehingga berperan juga sebagai penyeleksi mikroba; meningkatkan perkembangan mikroba tertentu dan menghambat perkembangan mikroba lainnya (Husen et al., 2008). Sebagai contoh diketahui bahwa unsur fosfor (P) dapat memacu pertumbuhan akar. Selain itu diketahui bahwa Azospirillum memiliki kemampuan melarutkan fosfat di dalam tanah menjadi fosfat tersedia bagi pertumbuhan tanaman (Rodriguez \& Fraga, 1999). Azospirillum juga merupakan salah satu komponen mikroba yang terdapat dalam Gliocompost.

Tanaman yang dipupuk dengan fosfor ternyata mempunyai akar yang lebih banyak dibandingkan dengan tanaman tanpa dipupuk. Hal ini disebabkan karena ketersediaan fosfor akan meningkatkan laju fotosintesis yang selanjutnya akan meningkatkan pertumbuhan akar. Ekstrak akar yang dipupuk dengan unsur P mempunyai aktivitas auksin yang berfungsi mempergiat pertumbuhan akar.

\section{Berat Basah}

Parameter kelima yang diamati pada peneitian ini adalah pengaruh pemberian Gliocompost pada media tanam terhadap berat basah bibit padi Pandanwangi (Oryza sativa L. var.Aromatic). Hasil uji ANOVA pemberian perlakuan Gliocompost pada media tanam terhadap berat basah bibit padi Pandanwangi menunjukkan pemberian perlakuan Gliocompost berpengaruh terhadap berat basah bibit padi Pandanwangi pada taraf $\alpha=5 \%$.

Tabel 5. Hasil ANOVA Pengujian Perlakuan Gliocompost pada Media Tanam terhadap Berat Basah Bibit Padi Pandanwangi (gram).

\begin{tabular}{cc}
\hline Perlakuan & Berat Basah (gram) \\
\hline P12) & $0,69 \mathrm{~b}^{1)}$ \\
P2 & $1,18 \mathrm{a}$ \\
P3 & $1,42 \mathrm{a}$ \\
P4 & $1,42 \mathrm{a}$ \\
\hline
\end{tabular}

1) Angka pada lajur yang sama diikuti oleh huruf yang sama tidak berbeda nyata menuru uji Tukey pada taraf $5 \%$ 2) P1 = Kontrol, P2 = Gliocompost $2 \mathrm{gr} / \mathrm{kg}$ tanah, P3 = Gliocompost $4 \mathrm{gr} / \mathrm{kg}$ tanah, P4 = Gliocompost $6 \mathrm{gr} / \mathrm{kg}$ tanah

Terlihat bahwa perlakuan P2, P3 dan P4 berbeda nyata dengan perlakuan P1 (Kontrol), hal tersebut terjadi karena ketiga perlakuan tersebut ditambahkan dengan aplikasi Gliocompost pada media tanamnya. Keberadaan Gliocladium sp. selain mampu menekan perkembangan penyakit juga dapat menyediakan ketersediaan hara bagi tanaman sehingga pertumbuhan tanaman berlangsung dengan normal (Iskandar dan Pinem, 2009).

Gliocladium sp. melakukan proses dekomposisi bahan organik yang berasal 
dari sekam padi dan pupuk kandang yang digunakan sebagai media tanam. Dalam proses dekomposisi tersebut Gliocladium sp. akan mengubah unsur yang ada dalam bentuk larut sehingga dapat diserap oleh tanaman. Oleh karena itu berat basah bibit padi Pandanwangi yang media tanamnya menggunakan aplikasi Gliocladium sp. memberikan hasil berupa berat basah yang tinggi karena nutrisinya terpenuhi dengan baik, sedangkan perlakuan P1 (kontrol) berat basahnya lebih rendah. Selain itu adapun Azotobacter sp., Azospirillum sp. dan Bacillus sp. menambat nitrogen dan menghasilkan fitohormon. Kemampuan Azospirillum sp. dalam menambat nitrogen dan menghasilkan fitohormon serta kemampuan meningkatkan penyerapan nutrien menyebabkan bakteri tersebut mampu meningkatkan pertumbuhan tanaman sebagai hasil asosiasi non simbiotiknya (Siddiqui, 2010; Tilak et al., 2010). Populasi mikroba di rhizosfer yang menguntungkan tanaman melalui beberapa cara, yaitu meningkatkan recycling dan pelarutan (solubilization) nutrien mineral; sintesis vitamin, asam amino, auksin, sitokinin, dan giberelin, yang merangsang pertumbuhan tanaman; dan antagonisme dengan patogen tanaman melalui kompetisi dan hubungan amensalisme berdasarkan produksi antibotik (Atlas and Bartha, 1994).

Berat basah tanaman merupakan berat kesuluruhan tanaman setelah panen dan sebelum tanaman mengalami layu akibat kehilangan air. Berat segar tanaman merupakan parameter untuk mengetahui biomasa dari pertumbuhan tanaman. Biomassa tanaman merupakan suatu ukuran hasil dari pertumbuhan tanaman yang di hasilkan dari reaksi-reaksi biokimia yang diawali dari penyusunan sel-sel yang akan membentuk jaringan kemudian akan membangun organ hingga pada akhirnya membentuk tubuh tanaman. Menurut Sitompul dan Guritno (1995) menyatakan bahwa biomassa tanaman meliputi semua bahan tanaman yang secara kasar berasal dari hasil fotosintesis, serapan unsur hara dan air yang diolah melalui proses biosintesis. Berat segar tanaman dihitung pada saat akhir penelitian dengan cara ditimbang secara langsung saat setelah dipanen dan sudah dibersihkan dari sisa-sisa tanah yang menempel diakar sebelum tanaman menjadi layu akibat kehilangan air. Berat segar ini dapat digunakan untuk mengetahui seberapa besar nutrisi dan air yang dapat diserap tanaman (Lakitan, 2008).

Berat segar suatu tanaman sangat dipengaruhi oleh status air. Status air suatu jaringan atau keseluruhan tubuh tanaman dapat berubah seiring pertambahan umur tanaman dan dipengaruhi oleh lingkungan yang jarang konstan (Goldsworthy dan Fisher, 1992). Menurut Lakitan (2001), berat segar tanaman terdiri dari $80-90 \%$ adalah air dan sisanya adalah berat kering. Kemampuan tanaman dalam menyerap air terletak pada akarnya. Kondisi akar yang baik akan mendukung penyerapan air yang optimal. Pertambahan berat segar disebabkan terjadi pembelahan dan pembesaran sel-sel dalam jaringan tanaman padi Pandanwangi. Pembelahan dan pembesaran sel-sel pada tanaman dipengaruhi dari hasil fotosintat yang diproduksi oleh klorofil. Jumlah klorofil pada tanaman dipengaruhi oleh unsur $\mathrm{N}$ sebagai bahan penyusun. Unsur nitrogen penting dalam pertumbuhan tanaman terutama sebagai unsur pembangun klorofil, lemak, enzim dan senyawa lainnya (Kurnia, 2008). Optimalnya pembentukan senyawa-senyawa dan biomassa pada tanaman maka akan meningkatkan berat segar tanaman sehingga berdampak pada hasil bibit padi Pandanwangi yang lebih baik.

\section{KESIMPULAN DAN SARAN}

\section{Kesimpulan}

Perlakuan yang paling baik yaitu perlakuan P2 (2gr/ kg tanah), P3 (4gr/ kg tanah) dan P4 (6gr/kg tanah). Aplikasi Gliocompost dengan dosis $2 \mathrm{gr} / \mathrm{kg}$ tanah (perlakuan P2) memberikan pengaruh paling baik terhadap benih berkecambah, 
banyak daun, panjang akar dan berat basah bibit padi Pandanwangi. Sedangkan untuk tinggi tanaman perlakuan yang paling baik yaitu perlakuan P4 (6gr $/ \mathrm{kg}$ tanah). Dengan kata lain aplikasi Gliocompost pada media tanam padi Pandanwangi ini memberikan pengaruh yang paling baik dibandingkan dengan tanpa pemberian Gliocompost.

\section{Saran}

Berdasarkan hasil dari penelitian yang telah dilaksanakan, untuk mendapatkan pertumbuhan vegetatif yang baik dianjurkan media tanam ditambahkan dengan perlakuan P2 (2gr/ $\mathrm{kg}$ tanah). Perlu adanya penelitian lanjutan tentang pertumbuhan tanaman padi Pandanwangi sampai dengan fase Generatif. Diharapkan sampel yang digunakan lebih banyak untuk kebutuhan analisis statistik lebih lanjut.

\section{DAFTAR PUSTAKA}

Atlas, R.M. dan R. Bartha. 1994. Microbial ecology: Fundamentals and applications. Fourth edition, Benjamin/Cummings, Addison Wesley Longman.

Baker, K.F dan Cook, R.J. 1974. The Nature dan Practice of Biological Control of Plant Pathogens. 3rd Edition: The American Phytopathology Society.

Bonde, M.R., G.L. Peterson. dan S.A. Rizvi. 1995. Research Program On Chrysanthemum White Rust At The Usda, North Amer. Plant Protection Organization. 141:4-18.

BPTPH (Balai Proteksi Tanaman Pangan dan Hortikultura) Provinsi Sulawesi Tenggara. 2010. Teknik Pembuatan Kompos dengan Menggunakan Agens Hayati. Leaflet. Laboratorium PHP Kendari.

Budiyanto, G. 2009. Bahan Organik dan Pengelolaan Nitrogen Laban Pasir. UNPAD Press.

Cutter, E.G. 1971. Plant Anatomy : Experiment and Interpretation Part II : Organs.. Addison Wesley Publishig Company. Ontario. 6-16.
Ekasari, P. 1994. Pengaruh Tingkat Kemasakan, Media Tanam dan Posisi Benih Ditanam terhadap Perkecambahan Benih Kemiri (Aleurites moluccana WILLD). Skripsi. Jurusan Budidaya Pertanian, IPB. Bogor. 59.

Fallik, E., Okon, Y., Epstein, E., Goldman, A. dan Fischer, M. 1989. Identification and quantification of IAA and IBA in Azospirillum brasilense-inoculated maize roots. Soil Biology and Biochemistry. 21(1): 147-153.

Goldsworthy, P.R dan Fisher, N.M. 1992. Fisiologi Tanaman Budidaya Tropik. (Terjemahan). Gadjah Mada University Press. Yogyakarta. 295.

Husen, E., Saraswati, R. dan Hastuti, R.D. 2008. Rizobakteri pemacu tumbuh tanaman dalam Metode analisis biologi tanah. Bogor: Balai Besar Penelitian dan Pengembangan Sumberdaya Lahan Pertanian. 191209.

Hutasoit, Nella. 2011. Pengaruh Pemberian Pupuk Nitrogen dan Pupuk Fosfat terbadap Pertumbuban dan Produksi Tanaman Cabai Merab (Online). (Nellahutasoit's Blog) Http://www.Nellahutasoit.Wordpr ess.Com.

Iskandar, M. dan Pinem, W.S. 2009. Uji Efektifitas Jamur (Gliocladium virens dan Trichoderma koningii) pada berbagai Tingkat Dosis terhadap Penyakit Busuk Pangkal Batang (Fusarium oxysporum f.sp. passiflorae) pada Tanaman Markisah (Passiflora edulis f. edulis) Di Lapangan. USU E-Journals (UJ).

ISTA (International Seed Testing Association). 2014. International Rules For Seed Testing. Switzerland $(\mathrm{CH})$ : ISTA.

Kurnia. 2008. dalam Bosco P.S. 2010. Respons Pertumbuhan dan Produksi Tanaman Jagung Manis (Zea mays saccharata sturt) Terhadap Pemberian Limbah Kopi dan Tepung Darah Sapi. Skripsi. 
Fakultas Pertanian Universitas Sumatera Utara Medan. Medan.

Lakitan, B. 2001. dalam Jahidah, D., 2016. Pengaruh Imbangan Pupuk Kandang Kelinci dan Pupuk N, P dan K Terhadap Pertumbuhan dan Hasil Tanaman Cabai Merah (Capsicum annum L.) Ditanah Regosol. Jurnal.

Lakitan, B. 2008. Dasar-Dasar Fisiologi Tumbuban. Raja Grafindo Persada. Jakarta.

Purnamaningsih, R. 2006. Induksi Kalus dan Optimasi Regenerasi Empat Varietas Padi Melalui Kultur In Vitro. Balai Besar Penelitian dan Pengawasan Bioteknologi dan Sumber Daya Genetik Pertanian. Bogor. Jurnal Agrobiogen. 2(2): 7480.

Putri, A.I. 2008. Pengaruh Media Organik terhadap Indeks Mutu Bibit Cendana (Santalum album). Jurnal Pemuliaan Tanaman Hutan. 21 (1): 1-8.

Rao, A.V. dan Venkateswarlu, B. 1982. Associative symbiosis of Azospirillum lipoferum with dicotyledonous succulent plants of the Indian desert. Canadian Journal of Microbiology. 28(7) : 778-782.

Rodriguez, H. dan Fraga, R. 1999. Phosphate solubilizing bacteria and their role in plant growth promotion. Biotechnol $A d v$. 17: 319-339.

Russel, S. 1977. Plant Root System. Their Funtion and Interaction With The Soil. Mcgraw Hill Book Company (UK) Limited London.

Santosa. 1993. Fisiologi Tumbuhan. Fakultas Biologi UGM. Yogykarta (Tidak Dipubikasikan).

Siddiqui, Z.A. 2010. PGPR: Biocontrol and biofertilization. Springer, Netherlands.

Sitompul, S.M. dan Guritno. B. 1995. Pertumbuban Tanaman. UGM Press. Yogyakarta.

Taiz, L. dan Zeiger, E. 1991. Plant Physiology.
Benyamin/Cumming Publishing Company. Tokyo. 219-247.

atty, A.R. dan Sumiyati, Y. 2009. Diseminasi Model Integrasi Lembaga Perwakilan Untuk Pendaftaran Sebagai Alternatif Pendaftaran Untuk. Memperoleb Perlindungan Hukum Indikasi Geografis Beras Pandan Wangi Cianjur. Laporan Hasil Penelitian Hibah Bersaing Lanjutan Yang Dibiayai Oleh Direktorat Jenderal Pendidikan Tinggi, Departemen Pendidikan Nasional, Sesuai Dengan Surat Perjanjian Pelaksanaan Hibah Penelitian Nomor: $\quad 040 /$ Sp2h/Pp/Dp2m/Iv/2009.

Wasito, A. dan B. Marwoto. 2003. Pengujian Keefektifan Gliokompos terhadap Pertumbuhan dan Perkembangan Tanaman Krisan. Jurnal.Hortikultura. 13(4) : 229-235.

Wattimena, G.A. 1988. Zat pengatur tumbuh tanaman. PAU IPB. Bogor. 145. 